\title{
Workers' Protests in Northern Portugal in the Transition from the Monarchy to the I Republic
}

\section{Célia Maria Taborda da Silva}

\author{
Ph. D, Professor of Contemporary History, Lusófona University of Porto \\ Email: celia.taborda@ulp.pt
}

\section{Doi:10.5901/mjss.2015.v6n2s5p115}

\begin{abstract}
The working class begins to be expressed in Portuguese society in the late nineteenth century, with the development of industrial capitalism and the consequent increase of workers in the industry. But it is in the early twentieth century that strengthens trade unionism and, with him, the statement of the labor movement. From here the working class associations distance themselves from the Socialist Party and betting in the labor union movement as a privileged vehicle of action, rescuing from the strike as a means of social demands. The Republic (1910) is in response to changing desires felt by the working class, watching up, from 1911, to a change in the structure and conduct of the union movement, which resulted in a series of strikes and completely destabilized the republican regime.
\end{abstract}

Keywords: Working class, protest, portuguese, monarchy, republic

\section{Introduction}

The industrialization process in Portugal occurred slowly throughout the nineteenth century, preventing the formation of a large and cohesive working class. In fact, before the industrialization, the word "class" was used as a reference to a group of workers, such as the craftsmen, artisans, artists, who, having acquired artistic knowledge and skills, enjoyed a certain social distinction (Mónica, 1986: 9). The concept of working class was born within the industrial era.

At the beginning, the factory workers were not highly qualified and only performed simple tasks. They came from rural areas near Lisbon and Porto and daily commuted to these cities to go to work, but, at the end of the day, they would return to their homes in the countryside (Fonseca, $2^{\circ}$ vol. : 19). This context prevented the manufacturing workers from having the notion of class consciousness and a sense of union. Actually, a long path would have to be followed before this class awareness became a reality.

The first trade unions were associations of crafts, reminiscent of the ancient brotherhoods of crafts, and shared objectives of cultural nature and mutual support (Cabral, 1988: 19), such as the assistance in disease states and death situations. Within a legal context, it could not be otherwise, since the associations of crafts had been banned in 1834 and their existence would only be permitted in 1891. However, the mutual associations proliferated in the two largest cities of the country between 1852 and 1856. In Porto, there were some associations of major importance: the associations of the weavers, tailors, carpenters, dyers, and printers. They all defended their crafts, but there wasn't a unifying center as there was in Lisbon. In fact, in 1853, the Centre for the Promotion of the Working Classes Improvement was formed in Lisbon; it was more structured and had the objective of promoting the association of the working class in Lisbon.

The mutual associations would have a new spirit in the 70s, inspired by the socialist ideology that was spreading in Europe. In 1871, Anselmo Lorenzo, Gonsalez Morago and Francisco Mora, three Spanish workers, members of the International Association of Workers (IAW), contacted Joseph Fontana and Antero de Quental, elements of the Centre for the Promotion of the Working Classes Improvement, in order to integrate the Portuguese working class in the international labour movement, which led to a new organization and new forms of action (Mónica, 1984: 36).

In 1872, and as a result of this approach by the IAW, the association Workers Fraternity was created. It was autonomous from the bourgeois framework and its statutes were influenced by the socialist ideology (Cabral, 1988: 20). A large number of workers with various trades joined the association and, in the same year, the fraternity opened a branch in Porto. However, the association was only successful during its first year of existence; in a few months the number of members decreased from 3,000 to 300 (Cabral, 1988: 46-47). In 1873, the outbreak of strikes showed that the dispersion still remained within the labour movement, with several associations competing against each other. Two of these associations merged as a consequence of this competition: the Associação Protectora do Trabalho Nacional (Protective 
Association of the National Labour) and the Fraternidade Operária (Workers Fraternity) became the Associação dos Trabalhadores da Região Portuguesa (Association of Workers of the Portuguese Region), with a federalist and trade union character (Monica 1984: 45).

In 1875, the Socialist Party was formed, presenting itself as a political force able to educate the working class, fostering its participation in the electoral games (Santos, 1994: 330). By that time, there were two parties in the Portuguese political scenario, the Restorative and the Progressive, which represented the forces of capital and industry. A year later the Republicans organized themselves as a political party and tried to link the labour movement to their ideals, using the protests of the workers to do so.

In 1903, through their newspapers $O$ Norte and $O$ Mundo, the Republicans made sure that the strike of the weavers in Porto was known across the nation. The Republicans had already exceeded the Socialists at the polls (in 1890 they had elected six members) and they aimed at leading the street protests.

The right of association, which was decreed in 1891, strengthened the union within the labour movement, though the working class was still not properly associated, even with the socialist party framework, as reported by Porto newspapers at the time. Actually, the socialist party failed to change the traditional electoral alienation of the working class, and even lost the influence it had in the labour movement, which was gained by the anarchists in the early twentieth century (Santos, 1994: 316. 317). In 1914, the creation of the União Operária Nacional (National Workers Union) at the Congress of Tomar marked the split between Socialists and Anarchists and the consequent collapse of the socialist workers' reformism, simultaneously affirming the union's autonomy from political parties (Cabral, 1988: 133).

In 1919, the Confederação Geral do Trabalho (General Confederation of Labour) was founded and the "crafts' unionism" gave way to a single union of labour activists, fighting for an ideal of social emancipation (Freire, 1992: 131).

In this article we will analyze the process of workers ' protest in Northern Portugal by acquiring rights, through the information that is recorded in the newspapers of the time, in the second half of the 19th century and early 20th century.

\section{The Workers' Protests}

In the 1870s, the workers in Northern Portugal started expressing their discontent through public protests. In Porto, in 1871, there were strikes organized by the milliners, tailors, dyers, butchers, and stampers. These workers were demanding higher wages and the reduction of the working hours. The wave of strikes continued in the following years and reached its peak in 1877 with the strike of the milliners.

The protests were a consequence of the introduction of machinery and the restructuring of the service that henceforth would be introduced in the Real Fábrica Social. The strike lasted a few days and the employers had to make some concessions: apprentices would only be admitted when it was necessary and the machines would be stopped if the excess of production jeopardized the workers' jobs (0 Protesto, 3-1877). This protest clearly demonstrated the importance of the milliners' corporative past and their privileged status, as if they belonged to the "workers' aristocracy".

In November, there was a new strike organized by the milliners at the factory Costa Braga, because of the regulation of the factories' entrances and exits. This was a difficult fight to keep, but with the help of the milliners' class from Lisbon the fight was won (O Protesto, 11-1877). In December, in Braga, at the factory Taxa and Faria, the milliners protested against the replacement of officials by apprentices (O Protesto, 12-1877).

The strength and power shown by the milliners was not extended to the other workers, as there was lack of unity among these latter. In the newspaper 0 Operário, created in 1878, by socialists from Porto, there were constant appeals to the Association of Workers, as a means of claiming better working conditions and salaries and as a way of fighting against the "injustice" and the "unrighteous" regulations which were imposed to the workers in the factories (07/13/1879).

In the eighties there were more strikes. This time it was the workers from the textile industry who organized a demonstration. In the North, in mid 1850s, there were strikes at the textile factories in Vizela and Crestuma and at Fiação Portuense. In the mid-1870s there were other factories involved, due to the low price of the cotton. In Guimarães two factories with more than 100 workers were set up. The decrease in the cost of raw materials led to an expansion of the textile industry, leading some manufacturers to mechanize their weavings (Mónica, 1986: 156). In Porto, the introduction of the machines was a problem for the weavers (O Operário, 07. 13. 1879); the weaving industry was responsible for the subsistence of whole families, as referred to by Oliveira Martins (minister) in the 1881 Industrial Survey, therefore, the lack of work was dramatic for these families. Perhaps for this reason the meetings of the weavers became more frequent.

1887 was marked by the workers' constant meetings in the North (attended by workers of both sexes). In February (1887), more than two thousand workers gathered at the Association of Porto. The workers proposed the creation of a committee to negotiate the rise and unification of salaries with the factory owners. They also asked for representation before the Parliament, the creation of trade union councils and the regulation of women and children labour. At the end of 
the meeting there was an appeal to the Association, as it was considered the only "powerful bulwark in the fight against capitalist exploitation" (O Protesto Operário, 06. 02. 1887). The textile industry employed many women and children, once they were cheap labour and usually did not belong to any type of organization or association. Despite these conditions, there are some references to the participation of women in the meetings organized by the Association. In the same year, at a meeting of weavers, one of the few women workers in the Workers Association, the name Rosa da Conceição, intervened and asked all workers to remain united, otherwise " the bourgeois would squeeze them as if they were bagasse" (Idem, 05. 08. 1887).

The 1890 crisis led to more strikes. In 1889, the milliners of Porto organized a general strike, which gathered about 1500 milliners, with the support of the milliners in the cities of Lisbon and Braga. They were demanding a raise, which they got after five months of fighting (Mónica, 1986: 46-47). In 1893, the workers of the factory Costa Braga went on strike for better wages, a reduction of their working hours to ten and a new Regulation for apprentices (Mónica, 1986: 48). Employers and workers did not come to an agreement and the situation dragged on and sharpened. There were clashes and arrests. This time, the weavers lost the battle and began to lose their claim force (Mónica, 1986: 49).

The turn of the century was particularly tragic for the working classes and their living conditions were progressively degrading. The political and economic crisis, which the country was not able to solve, was reflected in all productive sectors. In 1903, the weavers of Porto went on strike. It was the biggest strike ever and it was widely discussed in the newspapers and the Parliament. For the first time in the labour history, 30,000 workers were on strike, with the support of all textile industry workers (Mónica, 1986: 177). They were asking for a salary raise, the decrease of the working hours, the abolition of fines, the measurement of the fabrics in front of the workers and the concession of priority to the weavers in recruitment processes at the factories (Mónica, 1986: 177). After three months of hard struggle, hunger, and misery, negotiations, intervention of the Government, and clashes with the police, the workers finally got a positive response to their claims: a salary raise, 10 hours of work per day, and the measurement of the fabrics in front of them; the payment of fines was not abolished, but the money concerning those payments was kept in an assistance box.

According to the Portuguese historian Maria Filomena Mónica, this strike was "one of the first genuinely proletarian mass movements of the Portuguese history" (1986: 185) and it may have influenced other movements in the North, as the protest of the textile workers of Santo Tirso. In July 1910, the workers of the largest factory in Negrelos, in the region of the Ave, went on strike. Their claims were similar to the ones in Porto; they were asking for better working conditions and a salary raise, since they earned half the wages of their fellows in Porto (Mónica, 1986: 187). The strikes were spreading to other factories, but the employers were not giving a positive response to their workers' claims. Nongovernmental party forces also failed at giving voice to these claims and demands.

\section{The Strikes in the Republic}

At the beginning of the twentieth century there were many strikes in Portugal, similarly to what was happening in Europe, namely in England, France and Germany,where there were clashes between employers and workers. The establishment of the Republic (October 1910) did not soothe the workers; on the contrary, it was the opportunity for them to ask the Republicans to pay the promises they had made when their party was in the opposition.

In 1910 there was still discontent among the working classes. The cost of living was increasingly higher and the wages and working conditions clearly worse. In the North, the wages ranged between 400 and 600 reis per day, which, according to Jornal de Notícias $(\mathrm{JN})$, was not even enough for a family of 4 to pay half month's expenses concerning commodity prices, bread, cereals, fish, meat, cod, olive oil and sugar (JN, 22/10/1910).

In October, the Federation of Labour presented their protest against the high prices to the Civil Governor of Porto. The Civil Governor guaranteed that the "government of the Republic" intended "to facilitate as much as possible the welfare of their workers and their economic life. " The same Governor asked the workers not to raise difficulties to a "new regime that needed to be consolidated" (JN 27/10/1910). His request was not complied with and the demonstrations and strikes soon began.

A month later, the employees of the Gas Company also presented their complaint to the Civil Governor. Their main claim was a salary raise. The Company was facing a difficult financial situation and was powerless to increase the workers' salary. In December, the workers went on strike. The strike was spreading to other workers, as the smelters of the factory Company Aliança, and entailed serious damage to other industries (JN, 7 -12-1910); the intervention of the City Council helped to quickly resolve the situation.

The Republic raised the workers' expectations and they considered their interests protected by this political regime, but they soon felt disappointed and frustrated. The first disappointment was related to the tenancy law. As housing was one of the serious problems of the working class, the Republicans announced a law to regulate the relations between 
landlords and tenants, but when the new law came out there was a profound disillusionment. The law did not establish protective conditions for the poor tenants and maintained the conditions imposed by Franco's law, allowing the quick eviction of houses (JN, 11/19/1910).

The second disappointment was related to the decree concerning strikes. The right to go on strike was proclaimed by the Republic, but the Provisional Government considered that the Parliament should be responsible for its regulation. As the working class soon began to make use of this prerogative, the government had to legislate. The Minister Brito Camacho, through the Decree of $6^{\text {th }}$ December, imposed severe regulation as far as the right to go on strike was concerned. The decree legislated on coalitions in general, on the ones of public interest and on those which could eventually be prepared by state employees, establishing the ways in which they could be carried out. According to the decree, strikes could not bring disrespect and violence against those who wanted to work (Comércio do Porto, 12/09/1910).

The regulation of the working hours was the third disappointment. The working class had long fought for alterations in the law concerning the weekly rest and working hours. The republican government's promise to alter the law had been kept, but the new legislation did not satisfy the workers. According to Jornal de Notícias, the law "not only was not regulating working hours, as it was promised, but also made worse the chaotic regime of the weekly rest" (JN, 14/01/1911).

The reaction to the new legislation was almost immediate. The milliners' class Association stated that they were poorly impressed with the "repressive strike law and the law concerning labour regulation and intended to protest" (JN, 01/17/1911). This class was suspicious about the republican regime for its bourgeois character and during the first Republic their suspicion was confirmed once they lost their vindicating power (Mónica, 1986: 58).

The other classes also became disillusioned and the first two years of the Republic were marked by 247 strikes, involving various industries, throughout the country (Cabral, 1988: 235). In the North, there were strikes in the textile, metallurgic, gas and transport industries. The workers' movement began diverging from the Socialist Party, as the latter only supported the general strike as a "last resource" and criticized the general strikes of 1912 (Cabral, 1988: 197). This party considered that the power obtained through elections was the proper way for the workers to achieve their demands. In 1913, taking advantage of the persecution that the democratic government of Afonso Costa was making to the trade union movement and in order to control trade unionism, the socialists convened a congress in Tomar. Nevertheless, the trade union movement was strengthened and the National Workers Union was formed, autonomously from the parties.

The strike was the extreme form of reaction of the working class against the capitalist employers, since other forms of protest, such as rallies and conferences, widely used by professional associations, were not really effective, though they gathered large numbers of workers.

From 1870 to 1910, the strikes aimed at increasing the wages, reducing the working hours and preventing fires in the plants; the strike represented the struggle of a group of workers against their employers. After the implementation of the 1st Republic, the strikes, once spontaneous movements, became organized ones, prepared and validated by trade unions.

The most obvious motivation for a strike is material, but to define the true motivations of workers we have to reconstruct the history of the working class from the beginning, as Edward Thompson stated (1968), seeking explanations beyond the words of its leaders.

After World War I, the voice of the workers changed its tone. The workers' action was no longer confined to the factory or to the place where there was confrontation between employers and employees and acquired the sense of class struggle. The social injustices were widely discussed, surpassing the workers' issues, and were projected onto other spheres of society, including the political power, bringing into light the republican system's own contradictions.

The claims of the working classes became visible and were felt throughout society, since the general strikes affected the normal functioning of institutions and even endangered the state itself. Trade unions, gathering most workers, guided this struggle (Freire, 1992: 130), fostered negotiation, and tried to solve the conflicts.

\section{Conclusion}

In the monarchic period, the workers could not associate with, much less to strike, making difficult the worker's union and the struggle for their rights.

The workers' protests became more relevant during the I Republic, as the vindicating process had been gaining strength since the beginning of the twentieth century and the workers had acquired class consciousness. The republican parties repressed the working class, suppressing constitutional guarantees, pursuing trade unionists and answering some of their protests with violence. The call for direct action was increasingly widespread by the Revolutionary Unionism and 
the labour movement, after the I War, exhibited a more ideological and political nature.

\section{Primary Bibliography}

\section{Newspapers}

O Protesto - 1877

O Operário - 1879

O Protesto Operário - 1887

Jornal de Notícias - 1910-11

Comércio do Porto - 1910

\section{Secondary Bibliography:}

Cabral, M. (1988). Portugal na alvorada do século XX. Lisboa: Presença.

Fonseca, C. (s/d). História do Movimento Operário. Lisboa: Pub. Europa-América.

Freire, J. (1992). Anarquistas e Operários. Porto: Afrontamento.

Mónica, M. F. (1982). A formação da classe operária portuguesa. Lisboa: Fundação Calouste Gulbenkian.

Mónica, M. F. (1984). O movimento Socialista em Portugal (1875-1934). Lisboa: Imprensa Nacional Casa da Moeda.

Mónica, M. F. (1986). Artesãos e Operários. Lisboa: Edições do Instituto de Ciências Sociais.

Santos, M. M. (1994). O partido socialista nos seus primeiros anos - duas eleições perdidas. Revista da Faculdade de Letras- História. II série. Vol. XI.

Thompson, E. (1968). The making of the English working class. London: Penguin books. 